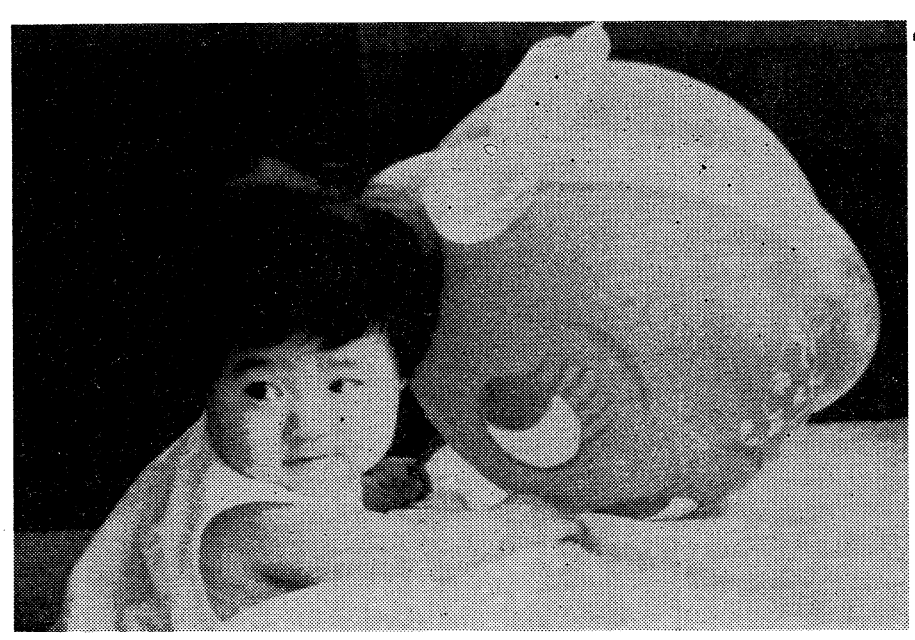

\section{䥲と眞珠首飾と風船 $(2)$}

(鎖狀分子の統計理論)
こでかかる格子鋇についての統計調查をや る方法としてまず考えられることは，ある きまった要素数の格子鎖がとり得るすべて の配位の中からできるだけ多くの配位を任 意抽出してそれについて調べるといら方法 である。すなわち一種のランダム・サンプ リングによる方法である。任意抽咄をする 方法としてはザイコロを使うとか乱数表を 用いるとかが考えられる。われわれはまず この方法を探用して実驗を行って見たが要 素数 100 までとって約 2 万回サイコロを 振った末にこの方法は適当でないことを認 めて断念した。といらのは要素数が 100 近 くにもなると可能な配位の数は全く超天文 学的数字となりその中から人閒能力的なわ ずかな配位を選んできてもとても正確な樣 子を傳えてくれそうにないし，その上にこ の方法によったものにはある柔統的な誤差 が入りそうであることがわかったからであ る。最近アメリカで本質的にはこれと同じ 方法で, サイコロを振るのを電子計算機に やらした結果が報告されている。たしかに

格子鎖 以上のごとく排除体積効果の問題に関して 調べられた理論的な結果は極めて定性的な結論しか與え ない。前にも述べたごとく理論的にこれ以上詳細な性質 を調べることは現在のところおぼつかない狀態にある。 そこで理論にたよらずになんらかの方法で排除体積効果 の影響をもっと直観的に知ることができればありがたい わけである。その一つとして試みた二次元の格子鏆に関 する統計調查の実驗結果をお話ししよう。

以下に取り扱う格子鎮というのは次のようなものであ る。第 7 罒に示したごとく二次元正方格子の單位正方形 の一辺を要素長として必ず直角に曲った鎖である。この 鎖において同じ格子点を折点が自由に共有できる。すな わちどんなにぶっかってもよいとした場合が理想折線錤

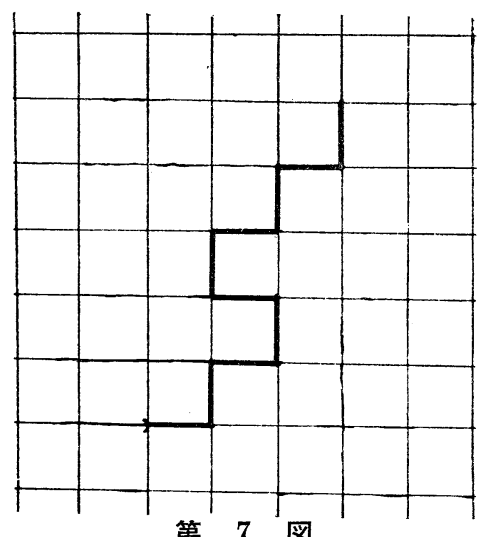

第 7 図
に対應し，二つ 以上の折点は同 一の格子点を共 有することがで きない。すなわ ちぶっかっては いけないとした 場合が排除体積 を完全に取り入 れた場合に相当 することは明ら かであろら。そ
竹槍と原爆の違いはあるがこの方法自身に疑問の点があ るので十分信用できるデータであるとは思えない。

さてこれに代る方法としてわれわれが探用した方法は 完全調查と呼ばれるものである。すなわち可能な配位を 全部書きあげて調べるのである。從ってこれから得られ る結果というのは完全に正確である。ただこの方法の欠 点は要素数がごく小さい範罒しか調べられないここであ る。しかしその結果は多くの重要な知識を與えてくれる ことができたように思う。その奏噞の方法执よび結果の 詳細を述べると長くなりそうだから，かいつまんで代表 的な結果だけを話すことにしよう。

総配位数 まず可能なすべての配位の数を調べてみ よう。ぶっかりの許された理想鎖の場合には各要素はそ の前の要素に対して必ず右か左の二通りの曲り方がある から要素数 $N$ の理想格子鋇の配位数は明らかに $2 \mathrm{~N}$ で ある（ただし最初の要素も必ず右か左へ向くとした場合 である。上下へ向いてもよいとすれば $2 N^{+1}$ となる)。一 方ぶっかりを除いた場合に可能な配位を書きあげて調べ てみると要素数 20 まで調べた結果 $2(1.60) \mathbf{N}$ といら式 でもって極めてよく表わすことができるといらことがわ かった。すなわち理想鎖のときには各要素が 2 通りの配 位が，とれたのがぶっからないようにすると各要素は本 均的に 1.6 通りの配位しかとれないようになるというこ とである。

分布函数 次に両端間の距離が $r$ と $r+d r$ にある 
確率を調べてみる。これに対しては 3 通りの結果が得ら れる。といらのは例えば第7 図を見て考えればよい。ま ず理想鋇の場合には実在型の場合でも生成型の場合でも この困の配位の起る確率は $(1 / 2)^{10}=1 / 1024$ である。何 となれば実在型の場合には $N=10$ のこの鎖のとり得る すべての $2^{10}$ の配位がすべて同じ確率で起るはずであ り，生成型の場合には各要素の步行が左右どちらか $1 / 2$ の確率で選ばれて図のごとき 10 回の步行を行ったはず であるから。これに反してぶっからないようにした場合 の実在型の問題では書きあげられたぶっからないすべて の配位が同じ確率で起るとするのであるから, その配位 数を調べると 220 で,從ってこの罒の配位が起る確率は 1/220 となる。次にぶっからないようにして一本づつつ け加えて行く生成型の問題とすればまずはじめの 5 回の 步行は左右両方に行けるから(1/2)づつの確率で方向を選 んで來たことになるが 6 回目および 8 回目の步行はぶっ からないよらにするにはそれぞれ右および左を選ばなけ ればならなかったのであるからこの図形を辿った確率は $(1 / 2)^{5} \times 1 \times 1 / 2 \times 1 \times(1 / 2)^{2}=1 / 256$ となる。このように 3 通 りの確率の計算の仕方が考えられる。それに應じて結果 も異なってくるはずである。第 8 図は両端間距離の確率 分布を $N=17$ の格子鎖について描いたものである。(a) 困はぶっかりを許した理想格子鎖に対するものであり (b) 困の実線涊ぶっらないようにした実在型の場合, 破線は同じく生成型の場合である。この図を見てわかる ことは分布の左右の対称性が排除体積效果を入れない理 想鎖と入れた場合とでほぼ逆といってよいほど全く相異
していることである。この傾向はもちろん $N=20$ まで のすべての場合について見られる顯著な事実である。こ れは極めて極端な例かも知れないがとに角排除体積効果 が本質的な影響をもっていることを㤗わしているように 思える。すなわち排除体積効果をとり入れれば (2) 式 のような分布函数は全く意味のない使えないものになっ てしまう可能性をほのめかしているようにも思える。も しそうであるとすれば今まで物性論の最も美しい成果の 1 つと考えられてきたゴム彈性論もその美しさの大牛を 失ってしまうことになりそうである。從ってこの辽で次 の話に移った方が無難であろう。

次にわれわれが覔珠首飾を使っていろいろと調べてき た両端間距離の 2 乘の平均值を上に述べた分布を使って 調べて見よう。〈 $\left.r^{2}\right\rangle / N$ を図示したのが第 9 図である。 ただし今の場合 $a=1$ とおいてある。点線が理想鎖の場 合でこれはもちろん一定で今の場合 1 である。ぶっか りを除くと最初のぶっかりは明らかに $N=4$ から起るか ら $N=3$ までは理想鎖の場合, すなわち点線と一致して $N=4$ からはづれてくる。そのはづれは常に奏在型の方 が生成型の場合よりも大きく, $N=20$ までのところでも 生成型の破線は何か一定值に收斂する可能泩を見せてい るのに反して央在型の実線は次第に横軸に対してある傾 斜をもった值線に近づくように見える。このことは 3 次 元の覓珠首䬦模型について得られた結論を支持している といってよいだろう。すなわち賽珠首飾の生成型では $N$ が十分大きくなれば〈 $\left.r^{2}\right\rangle$ は $N$ に比例する。いいかえれ ば〈 $\left\langle r^{2}\right\rangle / N$ は次第に一定值に近づくという Hermans の 計算に詨して少なくとも否定 的ではない。また実在型の場 合に対して得られた（6）式 は 3 次元であるが同じ計算を 2 次元の畣珠首飾模型につい て行うと

$$
\left\langle r^{2}\right\rangle=N a^{2}\left[1+\frac{1}{2} N\left(\frac{b}{a}\right)^{3}\right]
$$

となる。すなわち $\left\langle r^{2}\right\rangle / N$ は $N$ と共に增加する直線に近 ら゙く。これも実驗と大体同じ

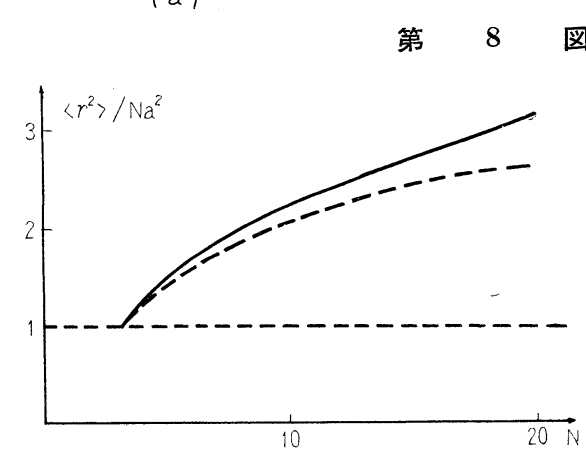

第 9 図
傾向を表わしているといってよいだろう。

このようにして排除体積効果に関して得られた第 1 表 の性質はこの範国では大体よさそうだといらことが実驗 の結果からも得られたわけである

問題はこれから＼cjkstart排除体積効果に対して述べた以上 の結論はまだ決してこれでいいというようなものではな い。はじめにも述べたごとくこれらの結諭は單に問題を 外から手さぐりでさぐってみた程度にすぎず，正確な結 論以前の見通しにすぎない。うまく行って予言というと 
ころである。実際には覓向からこの問題にぶっかって正 直に解くべきである。そのためには複雜な具珠首飾模型 よりも格子鎖を対象とした方が得策であろう。実際第 8 図の分布を見てもわれわれが普通使っている理想鎖とは すっかり变った型になることがわかるが，こうしたこと がはっきりと示せるような理論的な計算ができれば愉快 であるに違いない。最もそのときにはゴム彈性論の方は その美しい色彩の大牛を失うことにはなるが，しかしそ うした計算は今のところ幸か不幸かそら簡單には成功し そらに思われない。数学的に極めてむずかしい問題のよ らである。計算がおぼつかないならぼせめてわれわれの 行った完全調查の実噞をもっと手早くやれるような計算 機を作ってもっといろいろな場合が調べられても目的は ある程度達成されるであろら。結局完全な解答は將來に またなければならない。

風船と折線鎖葀が大分長くなってしまったがもう 1 つだけつけ加えておきたいのは風船の話である。これ ははじめの方で述べたように理想折線鎖に対する確率分 布の式 (2) が $r \ll N a$ の範团でのみ使える近似式で, $r=$ $N a$ で0にならないという久点を補うための話である。 実際に $r=N a$ で 0 になって $r \ll N a$ では (2) に一致す るような分布函数としては例えばランジュバン函数を使 って表わしたものがある。これはいろいろの敉科書にも 出ているのでここではもっと初等的な考え方でそれと似 た結果を求める方法を紹介しよう。

そのためにわれわれはまだ (2) 式の導き方を知らない 昔にかえって，もっと幼稚な頭でもって鎖の問題を解か せられる試驗を受けたと考えよう。そのときに私のごと き劣等生が考える解答が次のようなごまかしである。今
長さ $N a$ の糸の両端を距離 $r$ をへだてて固定したとき その糸を張って空間を動かすと一つの回轉楕円体が描か れる。2 次元の場合に同じことを考えればこれは楕円を 糸を使って書く方法に外ならない。この回轉棈円体の体 積は簡單に求まって $V=\pi(N a)^{3} / 6 \cdot\left\{1-(r / N a)^{2}\right\}$ である。 長さ $N a$ の折線鎖の両端をこの棈円体の焦点に 固定し て打けば鎖の $N$ 個の要素はとにかくこの回轉棈円体の 內部で複雜な運動をすることになる。そこで折線鎖の統 計的な性質はちょうどこの回轉楕円体の中に入れられた $N$ 個の粒子からなる 完全氣体と近似的に同じようなも のであろらと考えるのである。こうして要素をばらばら にしてしまえば後は完全氣体の計算になるから至極簡單 になってしまう。確率分布も容易に求められて

$$
\begin{aligned}
& P(\boldsymbol{r})=C\left\{1-\left(\frac{r}{N a}\right)^{2}\right\} \\
& C=\left\{2 \pi(N a)^{3} B\left(N+1, \frac{3}{2}\right)\right\}^{-1}
\end{aligned}
$$

となる。ただし $B(N+1,3 / 2)$ はべーター隶数である。 これをみると $r=N a$ では明らかに 0 となりまた $r \ll N a$ のときには

$$
P(\boldsymbol{r})=\left(\frac{1}{\pi N a^{2}}\right)^{\frac{3}{2}} e^{-r^{2} / N a^{2}}
$$

となることがわかる。ここで再び現代にもどってこれを もとの (2) 式と比較してみると完全には一致していない がちょうど（2）で $a$ を $\sqrt{3 / 2} a$ とおいたものに一致す ることがわかる。この不一致はいやなことには違いない が今の近似が随分粗っぽいものであることを思えばむし ろらまく出てきた方を喜ぶべきであろう。それに (2) 式 安実際に使らときには $a$ というのは実驗と比べてその大

\section{高分子アンケートについて}

現代はエネルギー的には原子力時代に入ろうとして いるが，材料の面では高分子時代が大きくクローズア ップされている。

天然高分子は古くから衣料その他の面に使用されて いたが，ナイロンを轉機 とする合成高分子の出現以 來, それは鉄, コンクリート, ガラス, 陶磁器などの 面を侵し, 工場における各種機械部品にあるいは各種 建築材料の面にあるいは種々な家庭用品の面に驚ろく べき速度で淮出している。しかし開き淔って "高分 子とは何か”と問われると一般の人々の中には案外 戶惑う人が多い。それどころかナイロンの鞉下を履 き，ビニルの風呂敖を持っている人が高分子といらも のを知らず，天然高分子を含めれ壮每日每日高分子の 厄介にならざるはなく，人間自身も高分子からできて いるにもかかわらず高分子といら言葉さえも知らない 人が多いのには驚ろかされる。これも学問科学として 新しいからだ。そこで一般人の良識がどの程度かを知 るために民間の各会社, 官廳, その他について昭和 29 年 11 月現在で高分子についてのアンケートをとって 見た。その結果は第 1 表の通りで, これを男女別, 年 齢層別, 調查対象別に分析してみると第 2 表〜第 4 表 のようになる。

\begin{tabular}{|c|c|c|c|c|}
\hline $\begin{array}{l}\text { 質問 } \\
\text { 事工 } \\
\text { 句 } \\
\text { 答 }\end{array}$ & \begin{tabular}{|l|} 
"高分- \\
知っ \\
Wる
\end{tabular} & 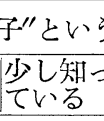 & $\begin{array}{l}\text { 言葉を } \\
\text { |知らな } \\
\text { 似 }\end{array}$ & 調查総人数 \\
\hline $\begin{array}{l}\text { 人数 } \\
\text { 句答率 }\end{array}$ & $\begin{array}{l}210 \text { 名 } \\
14 \%\end{array}$ & $\begin{array}{l}270 \text { 名 } \\
18 \%\end{array}$ & $\begin{array}{c}1000 \text { 名 } \\
68 \%\end{array}$ & $\begin{array}{c}\text { 1480名 } \\
\text { (男1010名，女470名) }\end{array}$ \\
\hline
\end{tabular}

$$
\text { この調查結果だけから全体のことに触れるのは㑿越 }
$$

第 1 表

第 2 表

\begin{tabular}{c|c|c|c}
\hline \hline 性 別 & 知っている & 少し知っている & 知らない \\
\hline 男 & $18 \%$ & $17 \%$ & $65 \%$ \\
女 & $7 \%$ & $21 \%$ & $72 \%$ \\
\hline \multicolumn{4}{r}{ 第 } \\
\hline
\end{tabular}

\begin{tabular}{l|c|c|c}
\hline \hline 年 齢 & 知っている & 少し知っている & 知らない \\
\hline 20才未溝 & $5 \%$ & $18 \%$ & $77 \%$ \\
20〜29才 & 19 & 20 & 61 \\
30〜39才 & 17 & 9 & 74 \\
40 才以上 & 0 & 20 & 80 \\
\hline
\end{tabular}

これは新しい学間を呚えられた人のみが理解し ていることを示す。

かも知れないが,およそ次の見当はつけられると思う。 まず調查の結果を全体から考察すると一般の人々の間 
きさを云々するパラメーターにすぎないのであるから， 実際に使ら面からいえばこの不一致はさして䦗題になら ない。(9) 式を使った $\left\langle r^{2}\right\rangle$ も簡單に求まって $\left\langle r^{2}\right\rangle=$ $3 / 2 \cdot N a^{2}$ となる。

風船模型による折線鎖の張力上に求めた分布が $r=N a$ で 0 になってくれるために生ずる最も顯著な性 質は鎖の張力が $r=N a$ で無限に大きくなることがでて くることであろう。実際風船模型を使ってこの張力を計 算してみると

$$
F(r)=2 N k T r /(N a+r)(N a-r)
$$

となる。第 4 図の破線はこれを示したものである。ラン ジュバン罒数を用いたものを使っても結果はほとんど同 じであることがわかる。またこの模型を使って実際にゴ ム彈性の計算をすることもできてその結果はパラメータ 一を適当に選ぶことによってほとんど完全に実驗と一致 させることもできる。しかし排除体積効果のところで述 ベたごとく理想鎖を使って計算することにどれだけ時味 があるのか全く疑問なのでゴム彈性にまで立ち入ること はここではしないことにする。

あとがき 以上鋇について随分ごたごたと長たらし いお話をしてしまった。はじめは肩のこらないようにと は思っていたが氣軗なアクセサリーの鎮が次第に何か重 くるしい存在になって肩のこるどころかがんじがらめに 鎖に縳りつけられて身動きのできない狀態になってしま ったような感じである。せっかく鋇狀分子を理想化して 数学的にもある程度きれいな形で便利に使われてきてい たものを徒らにつつきまわしてわけのわからないことに してしまった感がないでもない。しかしくわしく調べて ゆくとこのように実在の鋇狀分子といらのはわれわれが

\begin{tabular}{|c|c|c|c|}
\hline 調查対象 & 知っている & 少し知っている & 知らない \\
\hline A & $33 \%$ & $67 \%$ & $0 \%$ \\
\hline B & 0 & 17 & 83 \\
\hline $\mathrm{C}$ & 12 & 35 & 53 \\
\hline $\mathrm{D}$ & 29 & 25 & 46 \\
\hline $\mathrm{E}$ & 0 & 0 & 100 \\
\hline $\mathrm{F}$ & 53 & 20 & 27 \\
\hline $\mathrm{G}$ & 0 & 12 & 88 \\
\hline $\mathrm{H}$ & 17 & 21 & 62 \\
\hline I & 0 & 0 & 100 \\
\hline
\end{tabular}

（註） A. 化瀻会社, B. 縣廳, C. 通座省, D. 商事会社, E. 銀行，F. 造船機械会社，G. 船会社，H. 精糖 会社, I. その他 (店員, 家庭主婦, 学生など) な拉調查に際して洔に高分子関係の仕事を專門 に研究している人は除外した。

には高分子という言葉は余り知られていないことがわ かる。すなわち一般人にとっては高分子といら言葉は 未だ單なる学術用語でしかなく，実際交化生活に近い にかかわらず実際には遥かに總遠いものであることが わかる。またこの結果汢男女別に見た場合は少し男の 方が余計知っているようであるが大差はなく，年龄別 では 20 代が最高で年寄りの方が知らないことは老人
普通に使っている折線鎖とは大分性質の異なったもので あるのかも知れない。といってそれにとって代るような いい模型を提出することもできないのではちょうど賞め るよりはあらをつついてけなすことによってその立場を 保っている映画の評論家に似てなさけない次第ではあ る。この㲽で打ち切って鎖の拘束から解放されることに しよう。(京大理学部物理)

\section{交献}

まず折線鎮の数学的取り报いを多少くわしく知りたい という希望に対しては

S. Chandrasekhar: Rev. Mod. Phys., 15, 1 (1943) が最も便利であろう。この論交のはじめの方にいわゆる random flight の問題の取り报いがくわしく解㙭されて いる。

排除体積效果を取り扱った覓珠首飾模型の計算は次の 論文に論じられている。実在型の計算は

R. J. Rubin: J. Chem. Phys., 20, 1940 (1952)

T. B. Grimley: J.Chem. Phys., 21, 185 (1953)

F. Bueche: J. Chem. Phys., 21, 205 (1953)

寺本英：物性論研究, 42, 24 (1951)

山本三三三：物性論研究，44，36 (1951)

また生成型の計算をしたものは

H. Hadwiger: Makromol. Chem., 5, 148 (1951)

J. J. Hermans, M. S. Klamkin and R. Ullman :

J. Chem. Phys., 20, 1360 (1952)

次に格子鎖の理論は

H. Frisch, F. C. Collins and B. Friedman : J. Chem.

Phys., 19, 1402 (1951)

E. Montroll: J. Chem. Phys., 18, 734 (1950)

格子鎖の実羷は

寺本英, 倉田道夫：未發表（目下整理投稿準備中） 風船模型の話は

寺本英：物性論研究，76，(1954）

を参照されたい。

が大学を出てから勉强が足らないことを示す。これを 調查対象別に見るとさすがに纎維, 紙関係会社の者は よく知っているが，その他は実際に高分子を材料とし て使用したり, それを取り报ったり，それに関連の深 いところでも余り知られていないことがわかる。以上 の結果加一般人の間にもっと“高分子”といら言 葉とその意味內容を沴み込ませ, その重要性を認識さ せることが必要である。しかしこのことは裏を返せば まだまだ高分子の領域が腐大で前途遼遠なるものがあ り，今後に期待すべきものの多いことを示唆するもの である。なおこの調查に際しても後で高分子について 盛んに質問を受け，問題の提出を望まれ，文化人が大 い関心と認識を高めようとしていることがわかっ た。終りに本調查に御協力下された方々に厚く御礼申 上げます。(東京工大大学院 大島康記)

註記：20 年前迄の科学は物理でも化学でも一般工, 農，医学でも分子量の少さいものを取り报っていたが 昨年ノーベル賞を受賞したスタウジンガー博士によっ て分子量 1 万以上のE大分子量のもつ各種の特性が探 求され，学閣と実生活の上に大きな革命をもたらしつ つあるもので高分子とはある意味で亘大分子のことで あり，われわれは高分子物質を食い，高分子物質をま とい, 高分子科学反碓の反復によって生命現象を営 み, 高分子物質で研学し, さらに新しい高分子合成物 質の創造によって豊かな文化生活を営みつつあるので ある。(荒井溪吉補記) 